\title{
Study of Bacterial Indicators in Water and Sediments from Al- Hilla River, Iraq
}

\author{
Jasim M Salman ${ }^{1 *}$, Atheer SN Al-Azawey ${ }^{1}$ and Fikrat M Hassan ${ }^{2}$ \\ ${ }^{1}$ College of Science, University of Babylon, Hilla, Iraq \\ ${ }^{2}$ College of Science for woman, University of Baghdad, Baghdad-Iraq
}

\begin{abstract}
The present study was conducted to study of some microbial pollution indicators such as - total count, total coliforms, fecal coliforms, E.coli and fecal streptococci from water and sediment of Al-Hilla River in middle of Iraq. Samples were collected over a period of twelve months from March, 2010 to February, 2011.The results showed variation in the number and density of microbial indicators between seasons and study sites. A highest number of bacterial pollutants recorded through spring and summer seasons. Many environmental factors affect the bacterial indicators such as solar radiation, temperature, water flow and organic matter. The present study showed high variation in quantitative and qualitative of bacterial indicators, also they could be used as a bio-indicator for pollution of both water and sediment in Hilla River.
\end{abstract}

Keywords: Bacterial indicators; Water pollution; Euphrates river; Hilla river-Iraq

\section{Introduction}

Pollution of the surface water by liquid and solid wastes is widespread in many countries. Most of wastewaters are disposed directly to rivers without any treatment. Today water has become the most exploited natural systems since man stored the earth [1]. Biological pollutants (human and livestock) as well as physical and chemical pollutants (temperature, oxides, salts and pesticides) have negatively influences on the microbial community in the water and sediments [2].

Bacteria are ideal sensors for microbial pollution of surface water because of their fast response to environmental changing [3].The use of bacteria as water quality indicators can be viewed in two ways, which were suggested by Baghel et al. [4] as the presence of such bacteria can be taken as an indication of fecal contamination of water and an indication of potential danger of health risks.

There are no unanimous opinions about microbial pollution indicators in aquatic systems, however, coliform group bacteria, especially total coliform bacteria (TCB) and fecal coliform bacteria (FCB), have been selected as water microbial indicators traditionally [5]. Coliform group bacteria generally don't cause danger to peoples or animals, but it indicates to presence of other disease causing bacteria in aquatic systems, FCB are a good indicator for human and warm-blood animals wastes tracking in to the aquatic systems [1].

The coliform bacteria are widely used indicators, which may be the total coliform that got narrowed down to the Fecal coliform and Fecal streptococci [6].

Many authors attempted to distinguish differences between faecal pollution of animals and human origin based on different resistance of isolated bacteria to antibiotics [7]. Also, they use the exposure of various animals and humans groups to antibiotics that changed markedly over time [7]. In this field US-EPA [8] has established FCB concentration limit of $(200 \mathrm{CFU} / 100 \mathrm{~mL})$ in the water for recreational and contact usages and equal to $(0 \mathrm{CFU} / 100 \mathrm{~mL})$ for drinking water.

Contamination of water by enteric pathogens has increased word wide [4,9-11]. Otherwise, Irvine and Pettibone [9] found the fecal coliform densities in water sample from the Buffalo river reach were several logs lower than in the sediment, but the bacteria densities in sediment were weakly correlation with particle size and organic matter.

Indicator bacteria levels fluctuated seasonally with an average of 79 of total coliforms and enterococci occurring during summer months [11].

Al-Hilla River has been studied by many authors especially in the sense of water quality such as heavy metals and PAHs [12,13]. Therefore, this study aimed to investigate the incidence of the bacterial indicator in water and sediments of Al-Hilla River that lies in Iraqi middle.

\section{Materials and Methods}

\section{Study area}

Euphrates River it is one of main irrigation systems in Iraq, especially in its middle sites. Al-Hilla River branch out from Euphrates River, after crossing the Al-Hindiya barrage. Six sites were selected along Al-Hilla River (Figure 1):

Site 1: in Al-Mussayab district before Euphrates branching.

Site 2: in Al-Shujaireia region after the branching and represent first site in Al-Hilla River, it is widely and slows river flow.

Site 3: in Sinjar region near Ancient Babylon city, it exhibit low discharge to the river in this site.

Site 4: in Al-Hilla city center, the river flow increase and the discharge to the river also increased. *Corresponding author: Jasim M Salman, College of Science, University of
Babylon, Hilla, Iraq, E-mail: jasimsalman67@yahoo.com

Received March 25, 2013; Accepted April 23, 2013; Published April 30, 2013

Citation: Salman JM, Al-Azawey ASN, Hassan FM (2013) Study of Bacterial Indicators in Water and Sediments from Al- Hilla River, Iraq. Hydrol Current Res S13: 001. doi:10.4172/2157-7587.S13-001

Copyright: (c) 2013 Salman JM, et al. This is an open-access article distributed under the terms of the Creative Commons Attribution License, which permits unrestricted use, distribution, and reproduction in any medium, provided the original author and source are credited. 


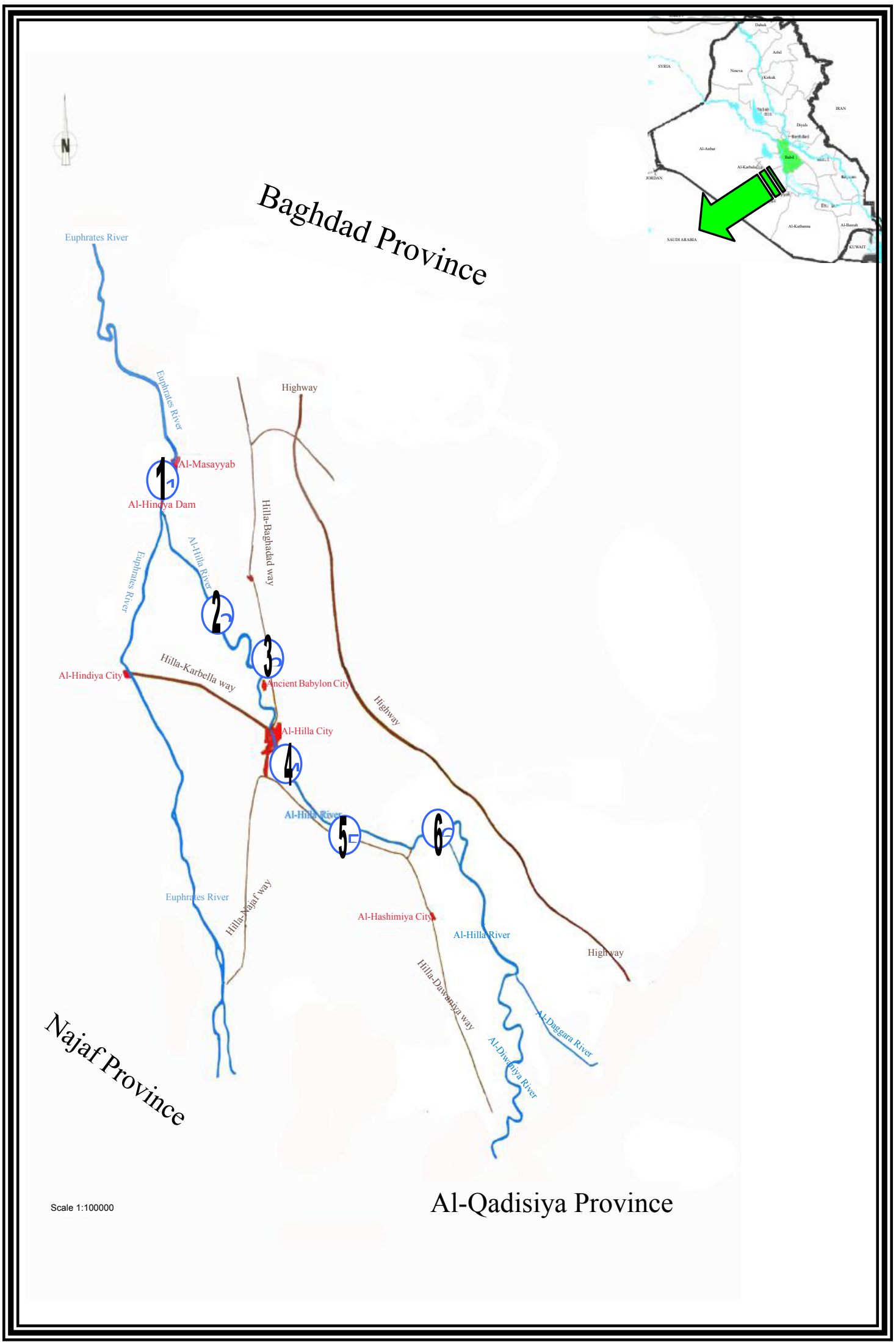

Figure 1: Map shows the studied sites in Al-Hilla River. 
Citation: Salman JM, Al-Azawey ASN, Hassan FM (2013) Study of Bacterial Indicators in Water and Sediments from Al- Hilla River, Iraq. Hydrol Current Res S13: 001. doi:10.4172/2157-7587.S13-001

Page 3 of 5

Site 5: in Al-Farisi region south of Al-Hilla city, high rate of effluent to the river, and

Site 6: in Al-Hashymiya city represent last sites in Al-Hilla River.

\section{Sample collection}

Water and sediments samples were collected monthly from March2010 to February2011 at six different sites. Samples were collected by using sterilized glass bottles, the collected samples were transport to the laboratory by ice box for analysis.

\section{Bacterial identification}

Total Viable Bacterial Counts (TVBCs) were determined by using the spread plate method and incubated at $22^{\circ} \mathrm{C}$ and $37^{\circ} \mathrm{C}$ [5]. The Total Count Bacteria (TCB) and Fecal Coliform (FCB) were determined by using Most Probable Number (MPN) method. One milliliter from each dilution was added to each of triplicate tubes containing $5 \mathrm{ml}$ of MacConkey broth, these tubes had been incubated at $37^{\circ} \mathrm{C}$ for $48 \mathrm{hrs}$ for Total Coliforms Bacteria and at $44^{\circ} \mathrm{C}$ (in water bath) for $24 \mathrm{hrs}$ for Fecal Coliforms Bacteria, positive result by formation gas that lead to rise derhum tubes, these tubes were complete the identification by microscopic examination and biochemical tests. Faecal Streptococci was determined by using of Azide Dextrose broth by MPN method at $37^{\circ} \mathrm{C}$ for $48 \mathrm{hrs}$, positive tubes was indicated by dense turbidity and formation ofpurple $[2,5]$.

Three decimal dilutions for each sample were established with three tubes for each dilution. MacConkey broth as presumptive tests determinations of TC and FC. The confirmation of TC test by using of brilliant green bile, finally this test is completed by Gram stain. In case of $\mathrm{FC}$, confirmation test was use $\mathrm{EC}$ medium at $44.5 \pm 0.5^{\circ} \mathrm{C}$ (by water bath).Fecal Streptococci was identify by MPN method that used azidedextrose broth in the presumptive test and was confirm by ethylviolet azide broth.

\section{Results and Discussion}

The distribution and seasonal variation of the Total Bacterial Count in the water and sediment of Al-Hilla river are shown in the Table 1 and Figure 2.

TVBC in this study ranged between $9 \times 10^{3} \mathrm{CFU} / 100 \mathrm{ml}$ at the site 2 and $68 \times 10^{3} \mathrm{CFU} / 100 \mathrm{ml}$ at the site 4 in the water samples and ranged between $11 \times 10^{3} \mathrm{CFU} / 100 \mathrm{ml}$ at the site 2 and $70 \times 10^{3} \mathrm{CFU} / 100 \mathrm{ml}$ at the site 1 in the sediment samples. This results indicating that the high values were recorded in the July and August-2010, respectively. Figure 2 reflecting the effect of high content of organic matter due to flourishing of phytoplanktons which increased active multiplication of bacteria [14].

The results revealed high level of TCB at different sites and seasons of current study (Table 1).The highest number of TCB was recorded during spring and summer, which might be the consequence of the high level of suspended solid and nutrients in the drainage water which affected the survival of aquatic microflora [15], or due to the positive relationship between temperature and bacterial levels suggests that heat induced growth may be a contributing factor to seasonally high bacteria levels [11],Wastes from agricultural processes, which are usually discharged into surface water have been reported to serious environmental and human health concern [16] .In this field, the results revealed high number of fecal coliform in the water and sediments from all study sites ranged between $11-155$ cell $/ 100 \mathrm{~mL}$ from water and $21-211$ cell $/ 100 \mathrm{~mL}$ from the sediments, respectively. Whitman et al. [17] attributed a gradual increase of E.coli bacteria in water and sediment during hot seasons to higher survival and growth at warmer temperature. Fecal coliforms are the best indicators for the assessment of recent fecal pollution, mainly caused by raw and treated sewage, and diffuse impacts from the farm land and pasture [3].

In this study fecal indicator bacteria abundance were measured in samples collected in large river located in rural areas. Data showed that this river which flowing through pastures was more contaminated than those rivers which flowing through agricultural areas [18]. The MPN of E. coli and fecal streptococci as indicator bacteria were ranged between $11-155$ cell $/ 100 \mathrm{~mL}$ and $9-20$ cell $/ 100 \mathrm{~mL}$ respectively in the water, and between2-211cell/100mL and $14-311$ cell/100mL respectively in the sediments.

The results showed the high variability in levels and number of bacterial indicators in seasons and sites in Al-Hilla River may be due to the variation of environmental conditions such as solar radiation, turbidity, temperature, salinity, dissolved oxygen and organic matter [1]. The minimum counts of the indicator bacteria were recorded in the warmer seasons, which might be attributed to the rapid die-off with increasing of solar radiation and high temperature [19].

A ratio between faecal coliforms and faecal streptococci were used to indicate the origin of bacterial pollution in the surface and ground

\begin{tabular}{|c|c|c|c|c|c|c|c|c|c|c|}
\hline \multirow{2}{*}{$\begin{array}{l}\text { Tests } \\
\text { Sites } \\
1\end{array}$} & \multicolumn{2}{|c|}{$\begin{array}{l}\text { Total Count }\left(\times 10^{3}\right) \\
\text { Cell } / 100 \mathrm{ml}\end{array}$} & \multicolumn{2}{|l|}{$\begin{array}{l}\text { Total Coliform } \\
\text { Cell/100ml }\end{array}$} & \multicolumn{2}{|c|}{$\begin{array}{l}\text { Faecal Coliform } \\
\text { Cell/100ml }\end{array}$} & \multicolumn{2}{|l|}{$\begin{array}{l}\text { E.coli } \\
\text { Cell/100ml }\end{array}$} & \multicolumn{2}{|c|}{$\begin{array}{l}\text { Faecal Streptococcus } \\
\text { Cell/100ml }\end{array}$} \\
\hline & Water & Sediments & Water & Sediments & Water & Sediments & Water & Sediments & Water & Sediments \\
\hline 2 & $\begin{array}{l}10-62.3 \\
(30.41 \pm 16.63)\end{array}$ & $\begin{array}{l}14-70 \\
(39.08 \pm 20.42)\end{array}$ & $\begin{array}{l}35-122 \\
(82.58 \pm 35.76)\end{array}$ & $\begin{array}{l}41-207 \\
(132.75 \pm \\
72.08)\end{array}$ & $\begin{array}{l}18-111 \\
(66 \pm 39.68)\end{array}$ & $\begin{array}{l}22-200 \\
(84.33 \pm 54.68)\end{array}$ & $\begin{array}{l}18-111 \\
(66 \pm 39.68)\end{array}$ & $\begin{array}{l}22-200 \\
(84.33 \pm \\
54.68)\end{array}$ & $\begin{array}{l}11-132 \\
(79.08 \pm \\
50.46)\end{array}$ & $\begin{array}{l}28-193 \\
(102.16 \pm 58.68)\end{array}$ \\
\hline 3 & $\begin{array}{l}9-60 \\
(30.06 \pm 17.10)\end{array}$ & $\begin{array}{l}11-62 \\
(37.46 \pm 20.81)\end{array}$ & $\begin{array}{l}31-123 \\
(79.5 \pm 38.46)\end{array}$ & $\begin{array}{l}40-208 \\
(133.83 \pm \\
73.49)\end{array}$ & $\begin{array}{l}15-114 \\
(66.33 \pm \\
43.71)\end{array}$ & $\begin{array}{l}27-187 \\
(83.08 \pm 53.21)\end{array}$ & $\begin{array}{l}15-114 \\
(66.33 \pm 43.71)\end{array}$ & $\begin{array}{l}27-187 \\
(83.08 \pm \\
53.21)\end{array}$ & $\begin{array}{l}12-140 \\
(84.25 \pm \\
51.47)\end{array}$ & $\begin{array}{l}29-180 \\
(103.33 \pm 55.83)\end{array}$ \\
\hline 4 & $\begin{array}{l}17-68 \\
(35.08 \pm 14.71)\end{array}$ & $\begin{array}{l}19-60 \\
(42.29 \pm 15.77)\end{array}$ & $\begin{array}{l}36-133 \\
(88.5 \pm 37.65)\end{array}$ & $\begin{array}{l}47-320 \\
(162.66 \pm \\
103.8)\end{array}$ & $\begin{array}{l}20-125 \\
(77.25 \pm \\
41.08)\end{array}$ & $\begin{array}{l}31-188 \\
(108.58 \pm 61.2)\end{array}$ & $\begin{array}{l}20-125 \\
(77.25 \pm 41.08)\end{array}$ & $\begin{array}{l}31-188 \\
(108.58 \pm \\
61.2)\end{array}$ & $\begin{array}{l}22-201 \\
(94.75 \pm \\
57.55)\end{array}$ & $\begin{array}{l}37-207 \\
(118 \pm 67.33)\end{array}$ \\
\hline 5 & $\begin{array}{l}19-66 \\
(39.5 \pm 14.22)\end{array}$ & $\begin{array}{l}23-64 \\
(47.75 \pm 15.46)\end{array}$ & $\begin{array}{l}38-138 \\
(96.58 \pm 41.04)\end{array}$ & $\begin{array}{l}55-397 \\
(214.91 \pm \\
133.4)\end{array}$ & $\begin{array}{l}28-155 \\
(91.25 \pm \\
46.86)\end{array}$ & $\begin{array}{l}39-211 \\
(125.75 \pm 68.3)\end{array}$ & $\begin{array}{l}28-155 \\
(91.25 \pm 46.86)\end{array}$ & $\begin{array}{l}39-211 \\
(125.75 \pm \\
68.3)\end{array}$ & $\begin{array}{l}32-200 \\
(107 \pm \\
58.13)\end{array}$ & $\begin{array}{l}41.311 \\
(141.5 \pm 81.88)\end{array}$ \\
\hline 6 & $\begin{array}{l}18-61 \\
(36.41 \pm 13.62)\end{array}$ & $\begin{array}{l}23-61 \\
(46.25 \pm 15.55)\end{array}$ & $\begin{array}{l}42-130 \\
(93.66 \pm 36.04)\end{array}$ & $\begin{array}{l}50-390 \\
(222.58 \pm \\
142.86)\end{array}$ & $\begin{array}{l}24-140 \\
(89.08 \pm \\
48.68)\end{array}$ & $\begin{array}{l}40-208 \\
(126.08 \pm 70.41)\end{array}$ & $\begin{array}{l}24-140 \\
(89.08 \pm 48.68)\end{array}$ & $\begin{array}{l}40-208 \\
(126.08 \pm \\
70.41)\end{array}$ & $\begin{array}{l}25-183 \\
(110.16 \pm \\
62.61)\end{array}$ & $\begin{array}{l}43-288 \\
(140.33 \pm 80.34)\end{array}$ \\
\hline
\end{tabular}

Table 1: The bacterial indicator count rang (Mean \pm SD) in water and sediments in Al-Hilla river during study period (March 2010- February 2011). 


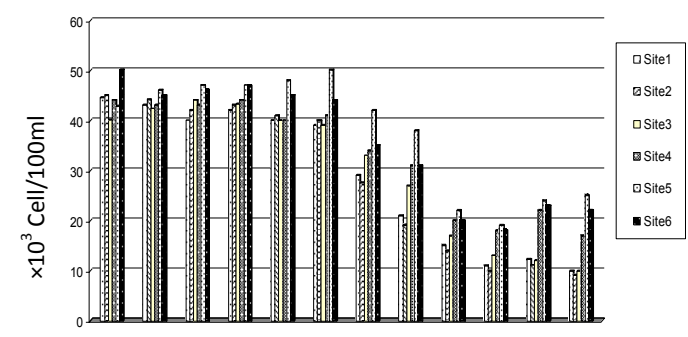

A1

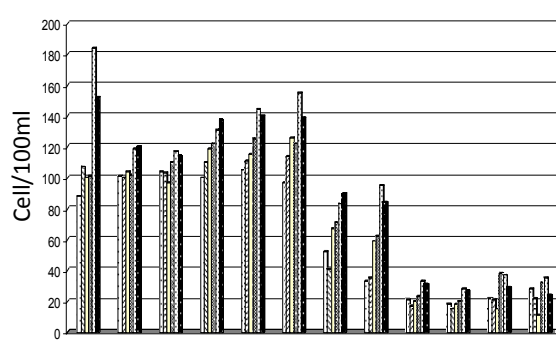

A2

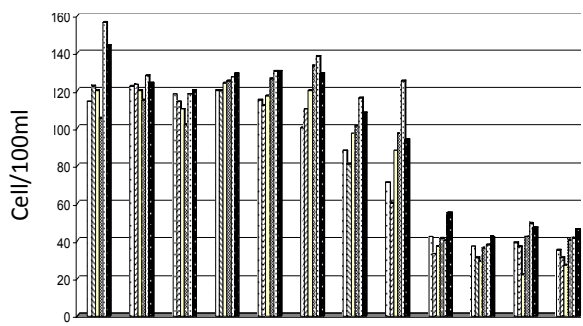

A3
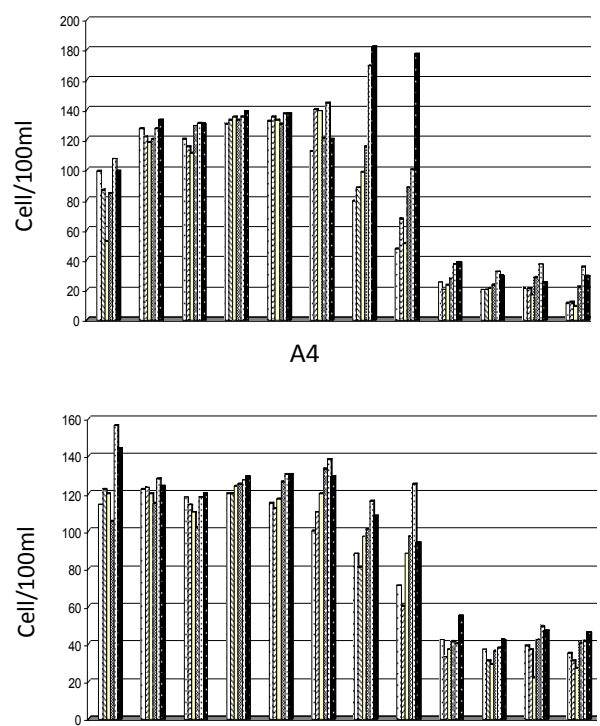

A5

Mar. Apr. May June July Aug. Sept. Oct. Nov. Dec. Jan. Feb.

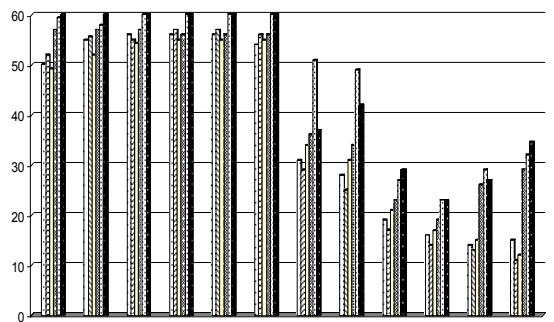

B1

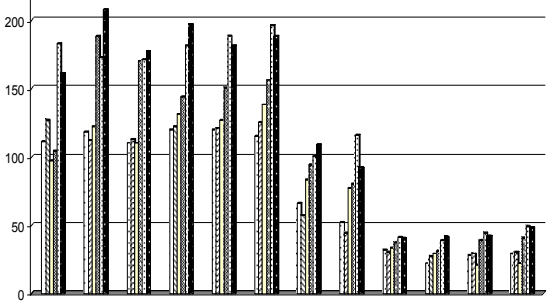

B2

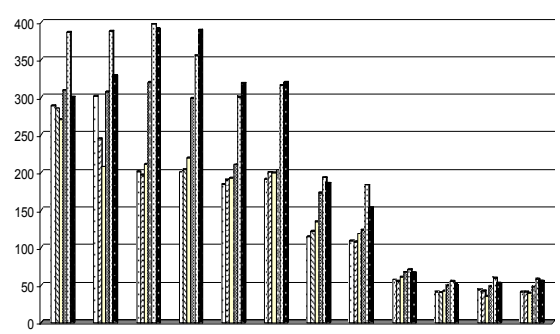

B3

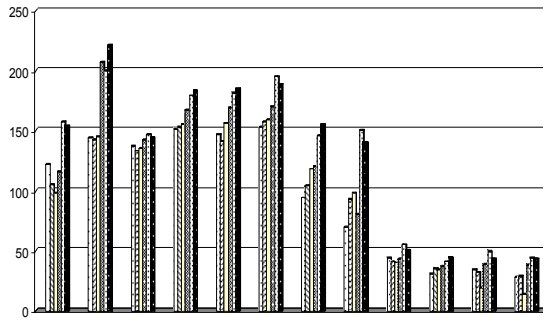

B4

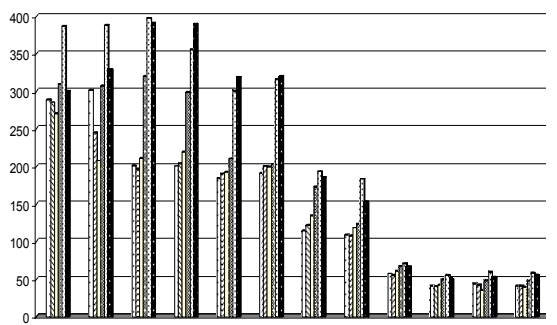

B5

Mar. Apr. May June July Aug. Sept. Oct. Nov. Dec. Jan. Feb.

Figure 2: Bacterial Indicators in Water and Sediments of Al-Hilla River. 
Citation: Salman JM, Al-Azawey ASN, Hassan FM (2013) Study of Bacterial Indicators in Water and Sediments from Al- Hilla River, Iraq. Hydrol Current Res S13: 001. doi:10.4172/2157-7587.S13-001

Page 5 of 5

water samples [7]. If the ratio is 4 or greater that indicate the human source of pollution, ratio between 0.1-0.6 indicate the domestic animal source, where as when the ratio is less than 0.1 that indicate the wild animal source of pollution. The results of current study indicate there is a mixed origin of fecal pollution in Al-Hilla river, because the domestic and agricultural wastes are discharged to the river [12,20]. According to WHO [21], the water and sediments of Al-Hilla river contain a high level of bacterial pollution; WHO recommended a mean value of $1000 \mathrm{MPN} / 100 \mathrm{~mL}$ fecal coliforms in the wastewater used for irrigating of vegetable, whether using of Al-Hilla river water for irrigation may increase the risk of spreading infection [22].

\section{Conclusion}

The microbial pollution of Al-Hilla River was assessed by monitoring of fecal indicator bacteria (E.coli and Enterococci) for the contamination in the water and sediments. Sediments of studied river contained high levels of bacterial indicators, where the maximum number of TCB and FCB were recorded in the spring and summer.

\section{Acknowledgments}

The authors would like to thank College of Science, University of Babylon and College of Science for Women, University of Baghdad, Iraq for their supports the project.

\section{References}

1. Yehia HM, Sabae SZ (2011) Microbial Pollution of Water in El-Salam Canal, Egypt. American-Eurasian J Agric and Environ Sci 11: 305-309.

2. Filimon MN, Borozan A, Sinitean A, Popescu R, Torok-Oance R, et al. (2010) Bacteriological studies on Timis and Bega rivers with a role in appreciating pollution. Annals of RSCB Vol XV, Issue 2 .

3. Kavka GG, Poetsch E (2002) Microbiology In: Technical Report of the International Commission for the Protection of the Danbue River. Eds. Peter Literathy, Veronika Koller Kreimel, Igor Liska. Eigenverlag ICPDR: 138-150.

4. Baghed VS, Gopal K, Dwivedi S, Tripathi RD (2005) Bacterial indicators of faecal contamination of the Gangetic river system right at its source. Ecological Indicators 5: 49-56

5. APHA (2005) Standard methods for the examination of water and wastewater, $21^{\text {st }}$ Ed. American Public Health Association, pp. 1200.

6. Kistemann AT, Claben T, Koch C, Dangendorf F, Fischeder R, et al. (2002) Microbial load of drinking water reservoir tributaries during extreme rainfall and runoff. Appl Environm Microbiol 68: 2188-2197.
7. Baudisova D (2009) Microbial pollution of water from agriculture. Plant Soil Environ 55: 429-435

8. US-EPA (2011) Protocol for Developing Pathogen TMDLs, EPA 841-R-00-002

9. Irvine KN, Pettibone GW (1993) Dynamics of Indicator Bacteria Populations in Sediment and River Water Near A Combined Sewer Outfall. Environmental Technology 14: 531-542.

10. Islam MS, Siddika A, Khan MNH, Goldar MM, Sadique MA, et al. (2002) Microbiological analysis of tub-well water in a rural area of Bangladesh. Appl. Environm. Microbiol 67: 3328-3330.

11. Tiefenthaler LL, Stein ED, Lyon GS (2008) Fecal Indicator Bacteria (FIB) Leve during dry weather from southern California reference streams. Southern California Costal Water Research Project, Technical report 542.

12. Al-Taee MMS (1999) Concentration of some trace elements in water sediments; aquatic plants and fish of Hilla river, Iraq.

13. Al-Azawey A.S (2012) Biogeochemical Distribution of some Polycyclic Aromatic Hydrocarbons (PAHs) in Al-Hilla River-Iraq.

14. Othman AA, Rabeh SA, Fayez M , Monib M , Hegazi NA (2008) The water quality of El-Salam Canal, North Sinai, Egypt. J Egypt Acad Soc Environ Develop 9: 47-64.

15. Hader DP, Kumar HD, Smith RC, Dobler WI (1998) Effects on aquatic ecosystems. J Photochem and Photobiol 46: 53-68.

16. Adams SB, Kolo RJ (2006) Public Health Implications of Gurara River around Izam Environs, Niger State, Nigeria. Fisheries Society of Nigeria (FISON). Conference Proceedings.

17. Whitman RL, Neveres MB, Gerovac J (1999) Interaction of ambient conditions and fecal coliform bacteria in southern Lake Michigan waters: monitoring program implication. Natural Areas Journal 19: 166-171.

18. Quattare NK, Passerat J, Servais P (2011) Fecal contamination of water and sediment in the river of the Scheldt drainage network. Environ Mnit Assess 183: $243-257$.

19. El-Shenawy MA (2005) Staphylococcus aureus and fecal indicators in Egyptian coastal waters of Aqaba Gulf and Red Sea. Egypt J Aquat Res 13: 113-124.

20. Al-Taee ATK (2010) Environmental study of Epipilic algae in Hilla river, Iraq.

21. WHO (1989) Health guidelines for the use of wastewater in agriculture. Report of WHO, Scientific group-technical report series 778, WHO Geneva.

22. Obasohan EE, Agbonlahor DE, Obano EE (2010) Water pollution: A review of microbial quality and health concerns of water, sediment and fish in the aquatic ecosystem. Afr J of Biotechno 9: 423-427. 